Journal of Management and Economic
Studies
2019, 1(4): 20-27 DOI: $10.26677 / \mathrm{TR} 1010.2019 .115$
Journal Homepage: $\mathrm{https} / / \mathrm{www}$.jomaes.org

\title{
Causes of Corruption in Nigeria: Implication for National Development
}

\author{
Salisu Ahmed Kabiru \\ Ya'adua University Katsina \\ Faculty of Social And Management Sciences Umaru Musa \\ Public Administration Department
}

\begin{abstract}
The purpose of this paper was to examine the causes of corruption in Nigeria as well as suggesting the Wayforward. This paper examines the root causes of corruption in Nigeria with a view to proffer solution to the menace. This study is a conceptual in approach, as such the paper utilizes secondary source of data collection and reflective method of data analysis was also utilized. Analytical findings shows that moral backwardness and greediness, were identified as some of the causes of corruption in Nigeria. This paper, therefore, suggest that to eradicate corruption the following measures must be taken, rebuilding the moral base of Nigerians, where the culture of integrity, honesty, sincerity, hard work, love for others and dedication will be encouraged.
\end{abstract}

Keywords: Corruption, Causes, Development

\section{Introduction}

The cause of corruption is contextual, because corruption is dynamic and varies from one region to another (Morris, 2008; Nwankwo, 2013). The term corruption is yet to have a universally accepted definition operationally or conceptually. The complexity of corruption as a concept is responsible for the difficulty in coming out with a universal cause of corruption around the globe. When corruption is viewed from religious perspective, it is seen as a deviation from the divine injunction, which can then be traced to the beginning of human creation.

But, when corruption is viewed from the modern concept of it, then the cause of corruption can be traced to situation such as economic, insecurity, high rate of income, meagre salary, the system of democracy (VI, 2010; Forson, 2016). The issues of causes of corruption, effect, and remedies are issues that attracted national and international policy makers attention over the past decades. This is because corruption has been singled out as the main obstacle that impair low income countries such as Nigeria from attaining a reasonable level of development, despite the abundant of natural and human resource that the country is blessed with. Although, 
corruption is over emphasized as the main problem of the developing countries, yet corruption is everywhere, and its encourage by developed nation through their multi-national corporation especially when it relates to natural resources and military weapons (Joda, 2010; De la 2015).

Corruption essentially, flourish where the institutions of government are very weak, and in society where there is high value attached to money and power. The consequence of this, will be wide disparity in wealth distribution, and this will lead to social problems such as arm robbery, kidnapping, terrorism, stealing, and high rate of poverty (Ijewereme, 2015).

Based on this backdrop, this paper examines the causes of corruption in Nigeria with the view of offering solution to eradicate the phenomenon. The paper uses secondary source of data for the study and analytical method was utilized as the tool for data analysis.

\section{Objective/Problem Statement}

The objective of this study was to examine the causes of corruption in Nigeria focusing on Moral backwardness, greediness, get rich quick syndrome, absence of private detective agency, delay in prosecution, duplication of anti-corruption agency, poverty, foreign collaboration, and absence of credible media. Corruption has become a pandemic in Nigeria spreading like a hurricane, affecting all aspect of social and economic development negatively where more than 90 million people are living below poverty line despite the natural resources which the countries is blessed with. The causes of corruption have to be identified in order to proffer solution to the problem which is the bane of Nigeria's underdevelopment.

\section{Literature review}

The term corruption was derived from the Latin word "corruptus" meaning to destroy. The word is used in this sense to indicates the destructive nature of corruption which affect every fabric of society where it is perpetrated (Nicholls, 2006). Corruption is a complex phenomenon and various factors and forces have conspired to cause it and spread it everywhere (T I, 2011). Studies from development studies perspective has attributed the failure of certain low-income countries to develop to corruption, and there are recent empirical studies which substantiate the link between corruption and lower investment, and growth in some developing countries (Mauro 1995; World Bank 1997). Despite the volumes of studies on corruption, yet, there is scanty empirical study that establish the main causes of corruption due to contextual differences, however, from the little studies that examine the causes of corruption, moral decadence is single out to be one of the main causes of corruption (Iroanusi,2006).

Other studies on corruption such as Farrales (2005), and Wasow (2011) indicated that, greed and the desire for power as well as the wish to advance oneself in society are primary reasons for corruption. Similarly, corruption usually prosper in societies that places high value on money, power and status in life (Akpa,2018). As asserted by Joda (2011), apart from greediness, the fall in education standard, poor maintenance culture, indiscipline, lack of patriotism, unhealthy competition for power and resources among politician, long military rule, civil upheaval, poor sectoral linkages, dishonesty, mis-presentation were some of the causes of corruption in Nigeria. Relatedly, Idris (2016) traced the causes of corruption to moral decadence, the decay in moral base of most Nigerians is obviously an underpinning factor for the growth and spread of corruption in Nigeria. In the same vein, Iroan (2006) submit that, the absent of moral behavior among leaders and the followers, prone people to compromises and once you compromise your values for greedy gain, the consequences transcend beyond taking bribe, and stealing, it goes to truncating the society's growth and development. From the perspective of systemic corruption, Stanley (2010), attributes the causes of corruption to 
discretionary power given to politician and bureaucrat which provide them with discretion over creation and interpretation of regulation which they manipulate for their personal gain.

\section{Methodology}

This study is a conceptual in approach wherein the data for study was collected using the secondary sources which include books, journals, newspapers, magazines and government publications, the study also uses reflective analysis as the means of analyzing the data gathered. Conceptual method has been for the very beginning of research been used to development new understanding about a phenomenon or interpret an existing phenomenon in a different way.

\section{Analysis and Discussion}

Under this section, the factors that causes corruption are analyzed and discussed which centers around moral backwardness, greediness, and get rich syndrome.

\subsection{Moral backwardness}

Morality can be seen as a set of standards which every individual is expected to strictly adhere to and any contradiction to the set standard attract punishment from the society (Joda,2010). Over the last decades, Nigeria as a society has witnessed a perennial moral setback not only among the youth, but even among the older people in the society. The decline in moral standard of most people in Nigeria is obviously the underpinning cause of corruption in Nigeria. When there is moral decadence in a society, people become susceptible to all forms of wrong doing especially corruption (Joda,2010). The moral base of most Nigerians today has been corrupted to the extent that, people doesn't see stealing government money as bad, rather they see it as an opportunity to have one own share from the national cake.

\subsection{Greediness}

Greediness is the intensity of selfish desire for wealth, power, and prestige, it is excessive interest in acquiring money or material things by individuals in the society. The excessive temptation in acquiring money or material things, especially by political leaders and bureaucrat in Nigeria was responsible for proliferation of corruption in Nigeria (Joda, 2010). This material obsession was once described by Waziri former EFCC chairperson as psyche disorder where an individual will steal money which is much more than his requirement for generation to come. EFCC has alleged that, about 20 trillion US dollar was stolen from Nigerian treasury from 1960 to 2005 by those who had access to the treasury. Furthermore, the Anti-Graft commission indicated that from the year 2000, about 100 billion dollars was stolen suggesting that the external debt of 33 billion dollar as of then will require only a fraction of the fund stolen by the leadership (Waziri,2010).

\subsection{Get rich quick syndrome}

The word get rich quick syndrome has been used since 1900 to describe shady investment deals which involve high rate of returns for the investor. But, within the Nigerian context, get rich quick syndrome is a situation whereby people especially the youth, are no more interested in making money through the right and legal way, rather they tend to engage into some illegal acts such as armed robbery, political thuggery, kidnapping, Yahoo and Yahoo plus, and money ritual (Agbo,2019, March 3). Average Nigerian youth are obsessed with getting rich quick, due to their perception that those entrusted with authority siphon the national treasury for their personal gain, as they misappropriate fund that is meant for the overall development of the country. Since every Nigerian youth dream to drive a jeep, wish to have a fantastic house, and own property worth of millions at home and abroad so they resort to illegal means of achieving their goal (Ribadu, 2012). 


\subsection{Absence of private detective agency}

An independent detective agency engages in a variety of activities such as investigating corrupt practices, tracing the origin and destination of illegal money, and other functions performs by independent detective include detecting drug trafficking, crime, terrorism, sexual harassment, detecting violation of intellectual property and infringement of copy right (Akpa,2018). Similarly, some independent detective act as witness where they give account of something they observed while they posed as undercover. In some part of the world, for example in USA the case of former president Clinton involving sexual relation with Monica Lewinsky was investigated by an independent investigator. This type of independent detective agencies are legally license to conduct investigative activities on behalf of the government, or on behalf of an individuals or organization (Ogbeidi,2012).

\subsection{Delay in prosecution}

One of the effective ways of controlling corruption is the establishment of an independent and effective judiciary. If the judiciary is not independent or is under the control of the either arms of the government especially the executive, the judicial system will loss public confidence as the judicial system will be compromise at the detriment of the ordinary citizen as what is apparent in Nigeria today, where judges are intimidated to pass arbitrary judgement. Similarly, the judicial system lacks the capacity to complete a court process within a reasonable time frame, and in some instances, the punishment for an offense is not commensurate with the magnitude of the offense, for instance, Bode Judge was convicted of corruption offences of 86 billion naira, but was sentence to two-years imprisonment without even forfeiting the money (EFCC, 2016).

\subsection{Duplication of anti-corruption agency}

Essentially, Nigeria has a plethora of laws that has been passed to eradicate or curtail corruption in the country. Most emphatically, the mere enactment of laws is not sufficient to stop corruption from being committed without enforcing the laws. For example, Akpa (2018) enumerated those laws and institutions that were created to eradicate corruption in Nigeria which include:

> The Failed Bank (Recovery of Debt and Financial Malpractice in Bank Act 1991)

> The Failed Bank (Recovery of Debt and Financial Malpractice in Bank Act 1994)

> The Advance Fee fraud and Other Related Offences Act 1995

> The Corrupt Practices and Other related Offices Act ICPC 2000

> The Money Laundering Amendment Act 2003

$>$ The Money Laundering Prohibition Act 2004

$>$ The Code of Conduct Bureau

> Due Process and Financial Intelligence Unit of the Budget Office

> Supervisory department of the Central Bank of Nigeria

> National Deposit Insurance Corporation

> Fiscal Responsibility Act 2007

From the above enumeration it is seen that, Nigeria has a good number of anti-corruption laws on the book that essential can eradicate corruption but, the reality is that, despite all these laws and institution, corruption is in the increase stagnating every aspect of Nigerian development progress. The continue blossoming of corruption cannot be attributed to lack of laws or 
institutions, but lack of integrity, sincerity, honesty, patriotism, fear of God, and the lack of courage on the side of the government and its anti-graft agencies in eradicating corruption (Ribadu,2010).

\subsection{Fear of poverty}

World Bank (2017) describes poverty as being in hunger, lack of shelter, being sick without the means to pay for seeing a doctor, poverty is lack of job, poverty is living one day at a time. In addition to lack of basic necessities of living, poverty is lack of capacity to participate in social functioning. The fear of all these, are some of the reasons people steal money from the government treasury or from any organization they are entrusted with fund. Poverty has eaten deep into Nigerian population where recent statistics indicated that over 90 million people are living below the poverty line which means that, those people are surviving on less than 1.9 dollar per day.

\subsection{Foreign collaboration}

Foreign government through their corporation encourage corruption by accepting Nigeria and other countries stolen money and stash in their banks, while at the same time they pretend as nothing is happening (Iroan, 2006). In most countries of the western world, it is very difficult to steal huge amount of money and stash in a Bank without being track down and prosecuted accordingly. For example, the former Head of Nigeria late Sani Abacha looted the government treasury which amount to billions of dollars and kept some of the monies in European countries, whereas they were fully aware that the money was stolen, but they turn a blind eye to it. Over the past years, a fraction of stolen money by Abacha has been recovered and return to Nigeria, while a substantial amount of the money is still stashed in European Banks (Iroan, 2006).

\subsection{Absence of credible media}

The ongoing thrive to purge out corruption out of the Nigerian shore is a noble course that worked well for other countries like Singapore, where the media has played a significant role in informing the citizen about what the government was trying to achieve in the fight against corruption. The Nigerian media for some time has been very closed, and pro-government, as such some vital information relating to government official are not usually disclosed by the media until recently when social media start to expose corrupt government officials. Information sharing is a vital mechanism for eradicating corruption without which no positive change can be achieve in the fight against corruption. The media should be in the forefront in informing people as to what they should do, and how they should go about it, and they should also inform the people about the consequence of their action and inaction (Joda,2010).

\section{Findings}

Reflective analysis shows that moral backwardness, greediness, get rich quick syndrome, absence of private detective agency, delay in prosecution, duplication of anti-corruption agency, poverty, foreign collaboration, and absence of credible media are some of the causes of corruption in Nigeria. Based on the analysis of this study, moral decadence and greediness are the two main factors that significantly influence corruption practices in Nigeria. For corruption to be eradicated in Nigeria, this paper argues that, people's moral and greed for worldly things must be reoriented toward good moral values and self-contentment.

\section{Conclusion/Implication}

From the available literature as highlighted by this paper, it has been established that, the moral base of Nigerians must be restored in order to eradicated and stamp out corruption from the 
society. Haven a good number of laws and institutions for fighting corruption is not enough to eradicate corruption as its evidence that despite all the laws and institutions, corruption has remained unabated in the society. One of the possible reasons for the ineffectiveness of the laws and the institution in curtailing corruption was the inability to trace the root cause of the problem, by tracing the root cause of corruption and apply the necessary measures to eradicate the root cause, then corruption will be eradicated in Nigeria. Unless the causes of corruption is rooted out in Nigerian society among which is moral decadence and greediness, the quest for Nigeria's national development will remain an illusion.

\section{Wayforward}

Corruption has permeated almost every strata of public life in Nigeria, having reached a pandemic level, it is one of the causes of the underdevelopment of Nigeria. Given the nature, and scale of corruption in Nigeria, it is difficult to eliminate corrupt practices completely in the society, but it can be minimizing to some certain level. A number of strategies or mechanism for curtailing corruption have been propounded by scholars such as (Okekecha,2013; Morris,2019), however this study itemized the suggested strategies for eradicating corruption as these:

$>$ One of the greatest preventive measure against corruption, is to rebuild the moral base of Nigerians, where the culture of integrity, honesty, sincerity, hard work, love for others and dedication will be the other of the day.

> Greediness should be discouraged in its ramification, people should be oriented to appreciate contentment, and the get rich quick syndrome should also be discourage among the Nigerian youth.

Dstablishment of an independent detective agency will significantly help in reducing corruption in Nigeria.

> Commensurate punishment should company any corruption offenses, if the fight is to be effective.

$>$ Rather than having strata of laws and anti-corruption institutions, effort need to be channel toward enforcing the existing law and empowering the institutions to do their assignment without fear and favor.

$>$ The media should be empowered to be in the forefront in exposing corrupt practices in both the public and private sector of the economy. 


\section{References}

Akpa, O. C. (2018). Neuroeconomics of Corruption: Feelings, Brain and the Nigerian Narratives (Doctoral dissertation, The Claremont Graduate University).

De la O, A. L. (2015). How governmental corruption breeds clientelism. Mexico's Evolving Democracy: A Comparative study of the 2012 elections. Retrieved from https://books.google.com.my/books?hl=en\&lr=\&id=hczxBQAAQBAJ\&oi=fnd\&pg=PA18 $1 \&$ dq=STEPHEN+D.+MORRIS+on+corruption\&ots=7kGyuX05I5\&sig=RpQPNFkNpFFj X_DRj2RQuscICKU\&redir_esc=y\#v=onepage\&q=STEPHEN\%20D.\%20MORRIS\%20on\% 20corruption\&f=false

Farrales, M. (2005). What is corruption?: A history of corruption studies and the great definitions debateshttps://scholar.google.com/scholar?hl=en\&as_sdt=0\%2C5\&q=What+is+Corrupti on $\% 3 \mathrm{~F} \% 3 \mathrm{~A}+\mathrm{A}+$ History + of + Corruption+Studies+and+the+Great+Definitions+Debate\&bt $\mathrm{nG}=$

Forson, J. A., Baah-Ennumh, T. Y., Buracom, P., Chen, G., \& Peng, Z. (2016). Causes of corruption: Evidence from sub-Saharan Africa. South African Journal of Economic and Management Sciences, 19(4), 562-578.

Idris, M. (2016). Corruption in Nigeria, causes, effect and remedies. Journal of Economic and Development, 1(4), 2-8.

Ijewereme, O. B. (2015). Anatomy of corruption in the Nigerian public sector: Theoretical perspectives and some empirical explanations. Sage Open, 5(2), 2158244015581188.

Iroanusi,S.O. (2006).Corruption: The Nigerian example. Lagos: Sam Iroanusi Publication

Joda,T.H.(2011). Anti-corruption handbook for Nigerian youths: A fundamental paradigm for rebranding education, business, politics and public administration. Zaria: Ahmadu Bello University Press.

Matukhno, N. (2014). Variance of corruption: Differential causes and consequences. Retrieved from https//scholar.google.com.scholar.

Mauro, P. (1995). Corruption and growth. The quarterly journal of economics, 110(3), 681-712.

Morris, S. D. (2008). Disaggregating Corruption: A Comparison of Participation and Perceptions in Latin America with a Focus on Mexico 1. Bulletin of Latin American Research, 27(3), 388-409.

Morris, S. D. (2019). Linking Crime and Corruption: The Case of Mexico. In Corruption in Latin America. America: Springer

Nicholls,C., Daniel, T., Bacarese, A., \& Hatchard, J. (2011). Corruption and misuse of public office. England: Oxford University Press.

Nwankwo, R. N. (2013). Official corruption and poverty reduction in Nigeria: a critical assessment (2003-2010). International Journal of Arts \& Sciences, 6(2), 305. 
Ogbeidi, M. M. (2012). Political leadership and corruption in Nigeria since 1960: A socioeconomic analysis. Journal of Nigeria Studies, 1(2).

Okekeocha C. (2013). A case study of corruption and public accountability in Nigeria (Master's thesis). Department of Political Science and International Affairs, College of Humanities and Social Sciences, Kennesaw State University, GA. Google Scholar

Ribadu, H. (2012). Corruption in Nigeria. Retrieved from the/ http://www.channelstv.com/home/wp-content/uploads/2016/Report-Of-Ribadu-LedPetroleum-Revenue-Special-Task-Force-2012.

Stanley,C.I.(2010). How Africa underdeveloped Africa. Port Hartcourt: Professional Printers and Publishers.

Transparency International (2011). Corruption Perceptions Index, Berlin: TI.

VI, N. L. T. (2010). The causes of corruption: Explaining the high levels of corruption in developing countries. Dallas: The University of Texas Press

Wasow, B. (2011). What trends in the prevalence of corruption has the world experienced in recent years?. Retrieved from https://www.theglobalist.com/a-very-brief-history-ofcorruption/

Waziri,F.(2009). How to fight corruption. Retrieved from https://efccnigeria.org/efcc/publicnotices

World Bank (2017). Corruption around the globe. The World Bank, Washington DC.

EFCC (2016). Conviction of corrupt persons. Retrieved from https://efccnigeria.org/efcc/images/CONVICTIONS2016.pdf

Agbo, N. (2019, March 3). An Influence in Get-Rich-Quick Syndrome? The Guardian 